\title{
Related Factors to Job Satisfaction in Selected Military Hospital Personnel: A Descriptive Cross-Sectional Study
}

Nehrir. B 1

Khamseh. $F^{2}$

${ }^{*}$ Moradian. $\mathrm{ST}^{3}$

1- Ph.D. Nursing (Medical - Surgical Management), Assistant Professor, Medical Surgical Department, Health Management Research Center, Baqiyatallah University of Medical Sciences, Tehran, Iran.

2- MSc (Psychiatric Nursing Education), Instructor, Mental Nursing Department, Behavioral Sciences Research Center, Baqiyatallah University of medical sciences, Tehran, Iran.

3- ( ${ }^{*}$ Corresponding Author) Ph.D. Nursing, (Medical - Surgical Management), Associate Professor, Medical Surgical Department, Atherosclerosis research center, Baqiyatallah University of Medical Science, Tehran, Iran.

Email: seyedtayebmoradian@ gmail.com

\section{Abstract}

Introduction: Job satisfaction is considered to understand the workforce in any organization in a good way. The concept of job satisfaction in the human resources development of military organizations is discussed. This provides to reach important business values and organizational effectiveness.

Objective: The purpose of this study was to determine the job satisfaction in selected military hospital personnel.

Material and Methods: This was a descriptive cross-sectional study. The study population consisted of personnel who work in selected military hospitals with a sample size of 186 individuals, according to entrance criteria and convenience sampling. Data were collected using a valid and reliable questionnaire of job satisfaction. Sampling was done from January 2018 to September 2018. The results were analyzed by SPSS 16.

Results: The mean age and work experience of the subjects were 31.58 (6.61) and 7.38 (5.92) years, respectively. Job satisfaction in $90.3 \%$ of subjects was medium and the highest satisfaction was related to the satisfaction of the manager $(67.2 \%)$. There was a significant relationship between job satisfaction and gender in Fisher's exact test $(\mathrm{P}=0.006)$ and the residential status in the chi-square test $(\mathrm{P}<0.05)$.

Discussion and Conclusion: The results showed that it is necessary for managers to continuously evaluate the job satisfaction of employees. Interference of nursing care and services with occupational conflicts and military constraints may be the causes of the decline in job satisfaction of nurses working in military hospitals.

Keywords: Cross-Sectional Study, Job Satisfaction, Military Hospital. 


\section{بررسى عوامل مرتبط با رضايت شغلى يرسنل بيمارستانهاى منتخب نظامى: يك مطالعه توصيفى - مقطعى}

بتول نحرير '، فريال خمسه'، "سيد طيب مراديان

جكيده

مقدمه: براى دستيابى به درك بهتر نيروى كار در هر سازمانى، ارزيابى رضايت شغلى در نظر گرفته مىشود. مفهوم رضايت شغلى در راستاى بالندگى منابع انسانى سازمانهاى نظامى مطرح است. اين موضوع رسيدن به ارزشهاى مههم شغلى و اثربخشى سازمانى را فراهم مى كند.

هدف: اين مطالعه باهدف تعيين رضايت شغلى يرسنل بيمارستانهاى منتخب نظامى انجام يذيرفت. مواد و روشها: اين مطالعه از نوع توصيفى- مقطعى بود. جامعه يزوهش كاركنان شاغل در بيمارستانهاى منتخب نظامى با حجم نمونه ع1ا نفر بر اساس معيارهاى ورود در يروهش به صورت هدفمند مشخص شدند. جمعآورى دادهها توسط يرسشنامه رواو واياى شاخص توصيفى رضايت شغلى صورت يذيرفت. انجام گرفت. نتايج با نرمافزار SPSS نسخه 19 بال سطح معنادارى ه • P P Pورد تجزيه و تحليل قرار كرفت.

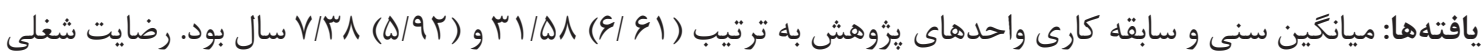
ك/ •9 درصد از واحدهاى يزوهش متوسط و بيشترين ميزان رضايت مربوط به رضايت از مسئول ( (9V/T) درصد بود. بين

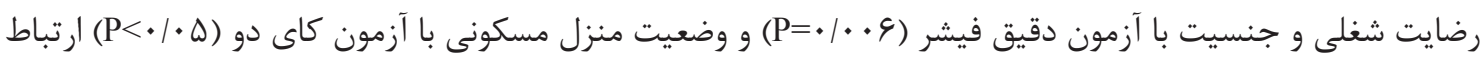
معنادارى وجود داشت. بحث و نتيجه كيرى: نتايج به دست آمده نشان مىدهد كه لازم است مديران به طور مستمر به بررسى رضايت شغلى

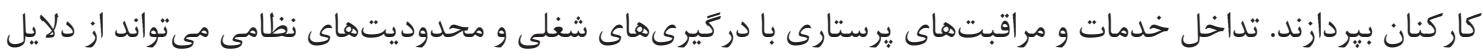
افت رضايت شغلى يرستاران شاغل در بيمارستانهاى نظامى باشد. كلمات كليدى: بيمارستان نظامى، رضايت شغلى، مطالعه توصيفى - مقطعى.

مجله علوم مراقبتى نظامى | سال ششم || شماره ع | زمستان

و خروج بالاى يرستاران از اين حرفه يك معضل جهانى است.

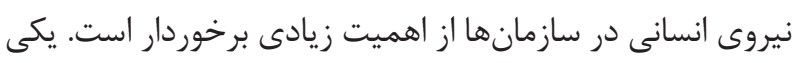
از مسائل مهمى كه در هر سازمان بايد مورد توجه قرار كيرد،

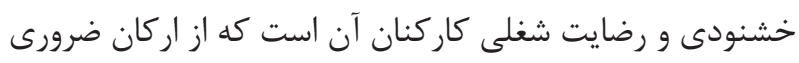

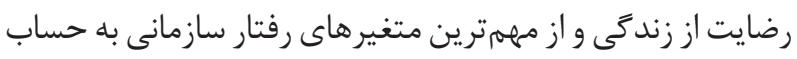

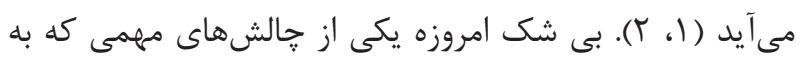

تقريباً در تمام كشورها عمدهترين بخش نيروى انسانى نظام

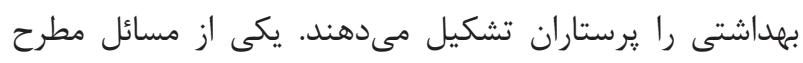

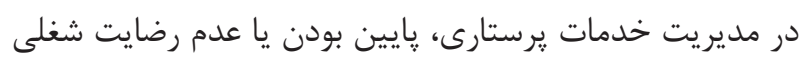

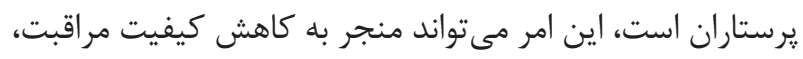

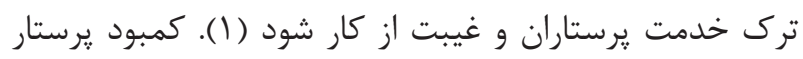


دانشعاه علوم يزشكى اروميه بر روى 199 يرستار، نشان دادند كه

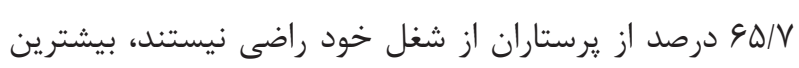

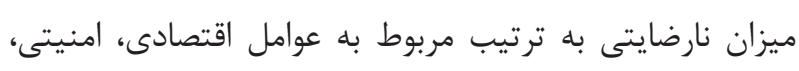

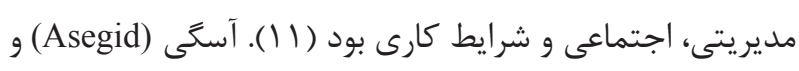

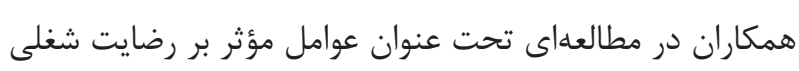

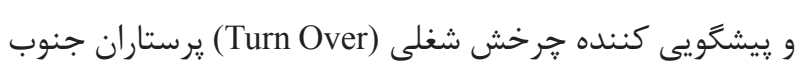

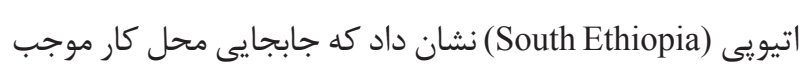

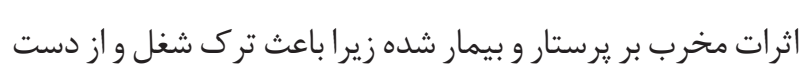

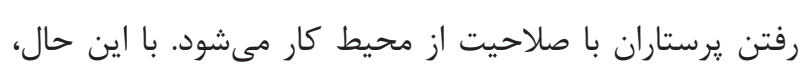

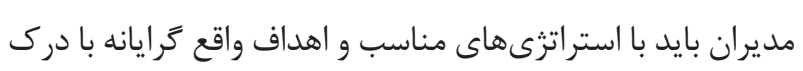

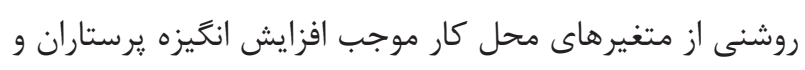

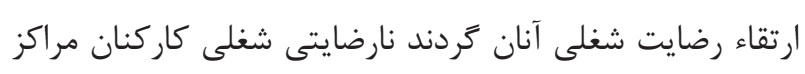
درمانى موجب يايين آمدن كيفيت خدمات ارائه شده و در نهايت

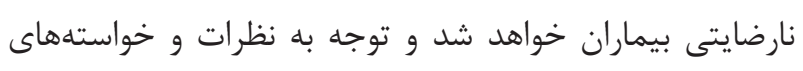

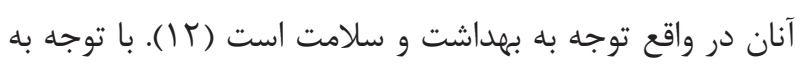
اينكه رضايت شغلى يرستاران به يك موضوع مهمم تبديل شده

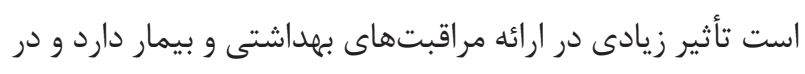
بيمارستان هاى نظامى يرستاران، مطابق با آيين نامه نقل و انتقالات

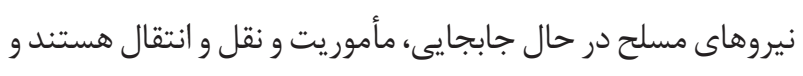
حساسيتهاى شغلى كار كنان درمانى شاغل در مراكز نظامى به نظر

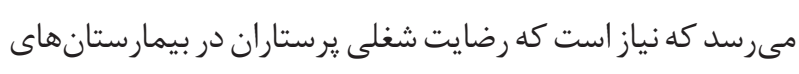

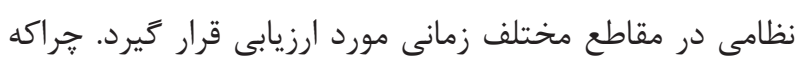

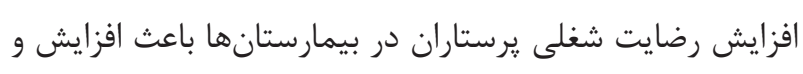
ارتقاء كيفيت خدمات درمانى مىشود و درنهايت رضايت بيماران را از خدمات درمانى بهبود مى بخشد. اين مطالعه با هدف تعيين

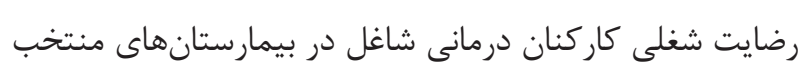

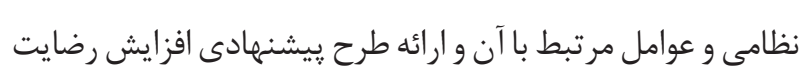
شغلى انجام يذيرفت.
Fونهاى فزاينده ذهن سريرستان و مديران را به خود مشغول نموده است، اندازهگيرى ميزان رضايت شغلى است (ب). رضايت شغلى

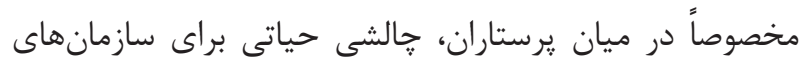
مراقبت سلامت است. از آنجا كه منابع هميشه محدود و هزينهها

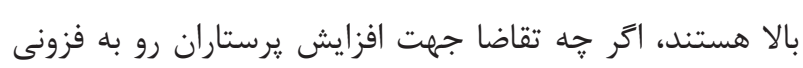
است، عرضه كافى جهت رفع اين تقاضا وجود ندارد (r). رضايت شغلى سازهاى است كه از دهه · ب9 ا به بعد بارها مورد مطالعه

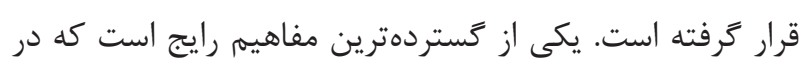
زمينه تحقيقات روانشناسى سازمانى - صنعتى مورد بررسى قرار كرفته و صدها تعريف از رضايت شغلى تاكنون ساخته شده است. به كَفته كارشناسان يكى از گ جالش برانگيزترين مفاهيم سازمانى و يايه بسيارى از خط مشى هاى مديريت براى افزايش بهرهورى و

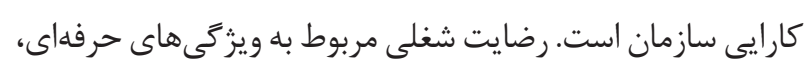
روابط با اعضاى تيم و انتظارات ذهنى در مورد محل كار و سازمان

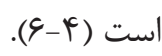
نحرير و همكاران در مطالعه توصيفى - همبستكى با عنوان ارتباط رضايت شغلى و تعهد سازمانى پرستاران شاغل در دو بيمارستان نظامى و غيرنظامى به اين نتيجه دست يافتند كه رفتارهاى تشويقى مدير، سبك رهبرى وى و عواملى كه موجب انخيزش كاركنان مىشود مى تواند بر رضايت شغلى و تعهد سازمانى كاركنان مؤثر باشد (V). رضايت شغلى به عنوان لٍاسخ عاطفى فرد به شغل

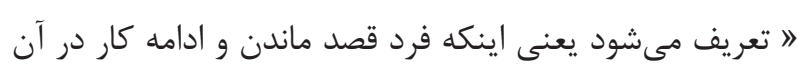

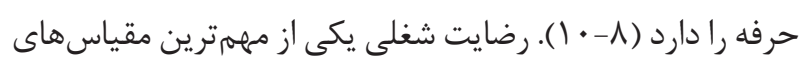
مستقيم اثربخشى است تا بهرهورى كاركنان را با توجه به شغل فعلى خود كه مستلزم پييخيرى مداوم است بهبود بخشد (9). همجنين از مهمرترين زمينههاى يزوهشى بوده و نقش آن به عنوان مؤلفهاى اصلى در سنجش سلامت سازمانى غير قابل انكار است. اين مفهوم عاملى مهمى در افزايش بهرهورى، افزايش روحيه، تعهد

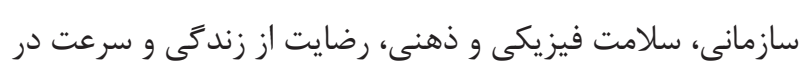
آموزش مهارتهاى جديد شغلى بوده و عدم وجود آن باعث به سهانه وجود آمدن تشويش، غيبت، تأخير كارى، ترى خدمت، اعتصاب و بازنشستخى زودرس كاركنان يك سازمان مىشود (ّ). موحد و همكاران در يزوهشى با عنوان بررسى رضايت شغلى و عوامل مؤثر

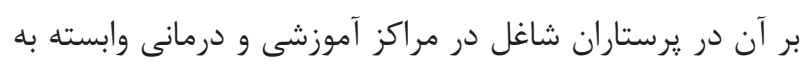


دانشعاه علوم يزشكى بقيه ا... (عج)، رضايت كتبى از واحدهاى

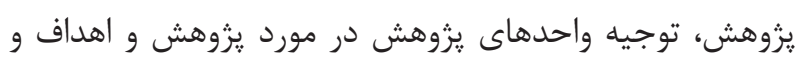
روش انجام كار دانست.

بافتهها

در بررسى نتايج مشخص كرديد كه از واحدهاى يزوهش عاه

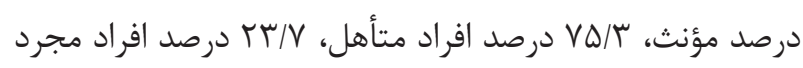

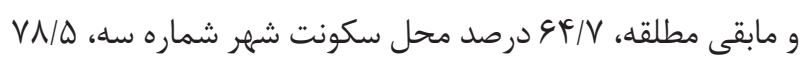

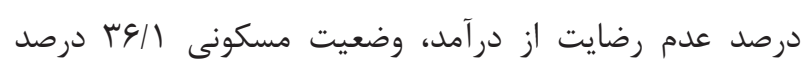

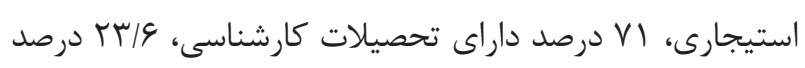

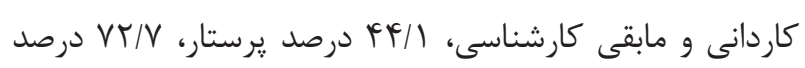

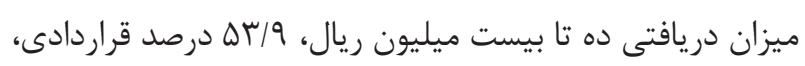

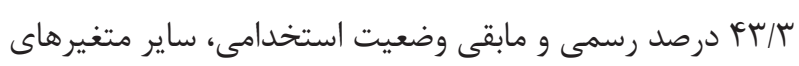

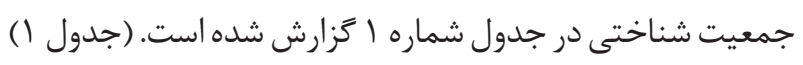

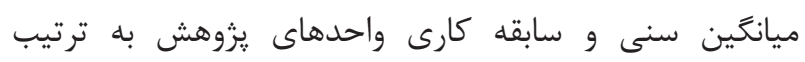
|

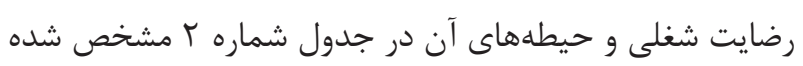

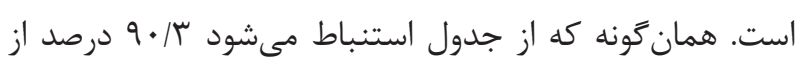
واحدهاى يزوهش رضايت متوسطى داشتند و بيشترين ميزان

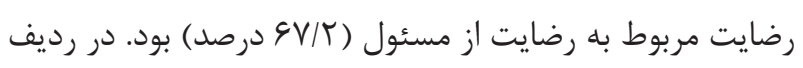

جدول ا- توزيع فراوانى متغيرهاى كيفى جمعيت شناختى در مشاركت

\begin{tabular}{|c|c|c|}
\hline & & كنندكان بزوهش \\
\hline فراوانى (درصد) & توصيف & متغير \\
\hline$\Delta \Lambda(\Psi \backslash / Y)$ & صفر & \\
\hline$\Delta \varphi(r \cdot / 1)$ & 1 & \\
\hline$\Delta \Gamma(Y \wedge / \Delta)$ & $r$ & تعداد فرزند \\
\hline $11(9 / V)$ & r & \\
\hline $1(\cdot / \Delta)$ & F أو بيشتر & \\
\hline 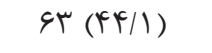 & يرستار & \\
\hline $\operatorname{lr}(9 / 0)$ & سر يرستار & \\
\hline$r T(\mid \varepsilon / F)$ & ماما & \\
\hline$q(Y / T)$ & هوشبرى & يست سازمانى \\
\hline $11(\mathrm{~V} / \mathrm{V})$ & اتاق عمل & \\
\hline $1 F(9 / 1)$ & علوم آزمايشگاهى & \\
\hline $\operatorname{Ir}(\Lambda / \mathcal{F})$ & راديولوزى & \\
\hline
\end{tabular}

W. Morgan)

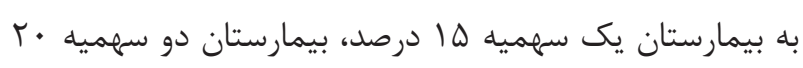
درصد و به بيمارستان سه سهميه • V درصد حجم نمونه اختصاص داده شد. نمونه واحدهاى يزوهش بر اساس معيارهاى ورود در يزوهش به صورت مبتنى بر هدف مشخص شدند. سيس در صورت تمايل افراد به شركت در مطالعه، رضايت آكاهانه جهت انجام مطالعه از آنها اخذ شد. يرسشنامههاى يزوهش در اختيار آنها قرار داده شد يس از راز حذشت مدت يكى هفته مجدداً يرسشنامهها جمعآورى و تعداد

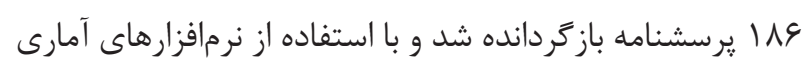
نسخه 19 مورد تجزيه و تحليل قرار گرفت. معيارهاى ورود به يزوهش شامل سابقه كار در بيمارستان منتخب نظامى به مدت

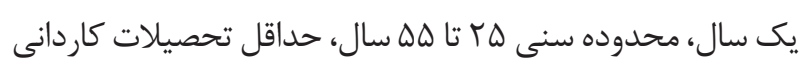
و معيار خروج از يروهش شامل نقص در تكميل يرسشنامهها به

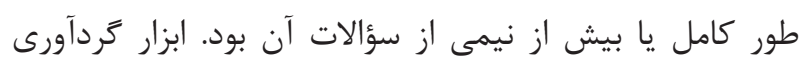

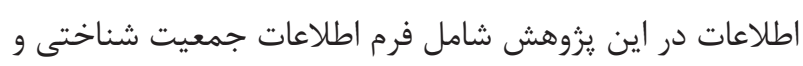
يرسشنامه بررسى رضايت شغلى (Job Descriptive Index-JDI) بود. اين مقياس توسط اسميت (Smith) و همكاران در سال 9199 ساخته شد. يرسشنامه مذكور بومى سازى شده و داراى اعتبار و يايايى لازم است و داراى هلهؤال بوده كه ينج مؤلفه زير را مىسنجد: ماهيت كار (Tr Tبارت)، سريرست يا مسئول مستقيم

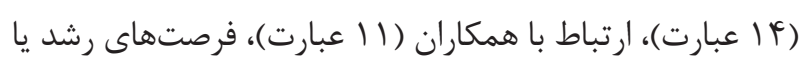
ارتقاء شغلى (V عبارت) و حقوق و مزاياى شغلى (F عبارت) (r I ). شر كت كنند

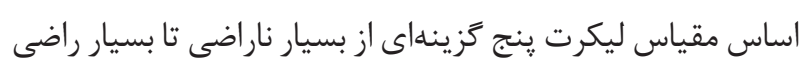

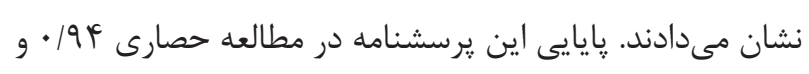
در مطالعه نحرير روايى ابزار با روش روايى محتوى تائيد شد؛ و ميزان يايايى با استفاده از روش آزمون- باز آزمون (Test re Test)

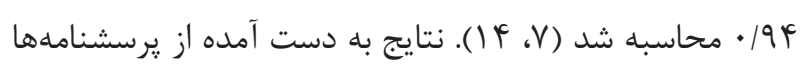
در نرمافزار SPSS نسخه 91 وارد شد. دادهها با آزمونهاى آمارى توصيفى و استنباطى در سطح معنادارى ه •/ P مورد تحليل قرار گرفت. يثوهشگر به منظور صيانت از ارزشهاى انسانى و و

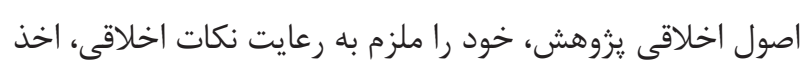

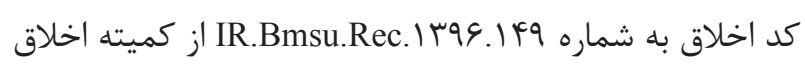


جدول r- توزيع فراوانى ميزان رضايت شغلى و حيطههاى آن در بين واحدهاى يزوهش

\begin{tabular}{|c|c|c|c|}
\hline فراوانى (درصد) رضايت & فراوانى (درصد) متوسط & 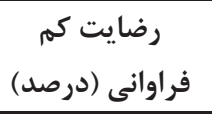 & حيطه \\
\hline$(r q) \backslash f$ & $\operatorname{lfQ}(\vee \wedge)$ & $10(\Lambda / 1)$ & خصوصيات شغل \\
\hline$(S V / T) \mid r \Delta$ & $\Delta \wedge(\Psi / / T)$ & $1(\cdot / 0)$ & رضايت از مسئول \\
\hline$(r q) \Delta r$ & $\Lambda G(Y G / T)$ & $\mu \wedge(r \cdot / \mathcal{F})$ & رضايت از همكار \\
\hline$(\mid r) T G$ & $9 f(\Delta \cdot 1 \Delta)$ & $\Delta \Delta(r q / \varphi)$ & ارتقاء شغلى \\
\hline$(r \Delta / \Gamma) F V$ & $11 \pi(9 \cdot 1 \Lambda)$ & $r(I T / Y)$ & حقوق و مزايا \\
\hline$(\boldsymbol{F} / \Gamma) \wedge$ & $19 \wedge(9 \cdot / r)$ & $1 \cdot(D / F)$ & نمره كل يرسشنامه \\
\hline
\end{tabular}

زنان رضايت شغلى كمترى داشتند. همجنين افرادى كه منزل

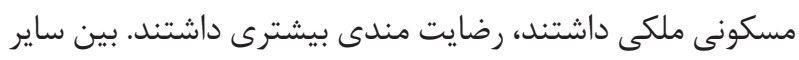

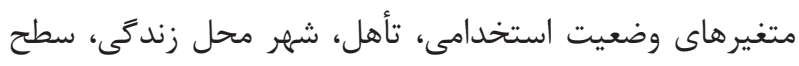

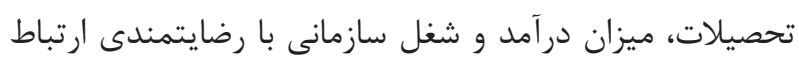

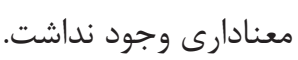
جدول شماره ه بيانكر نمره كل رضايت به تفكيك سه بيمارستان

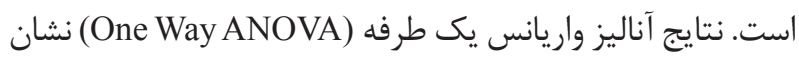
داده كه ميزان رضايت بين سه بيمارستان با هم تفاوت معنادارى

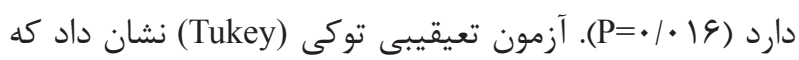

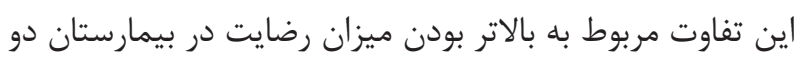
نسبت به بيمارستان سه و يك است.

\begin{tabular}{|c|c|c|}
\hline \multirow{2}{*}{$\begin{array}{c}\text { آزمون آناليز واريانس } \\
\text { يك طرفه }\end{array}$} & ميزان رضايت شغلى & \multirow{2}{*}{ بيمارستان } \\
\hline & فراوانى (درصد) & \\
\hline \multirow{3}{*}{$\begin{array}{l}\mathrm{P}=\cdot 1 \cdot 19 \\
\mathrm{~F}=|/ T| q \mid\end{array}$} & $(11 / \cdot \Delta) F \wedge / T K$ & بيمارستان يك \\
\hline & $(\Lambda / I V) \Delta F / I I$ & بيمارستان دو \\
\hline & $(q / T q)$ Fq/F & بيمارستان سه \\
\hline
\end{tabular}

رضايت كم بيشتر ين فراوانى مربوط به ارتقاء شغلى (9/9 د درصد)، در رديف رضايت متوسط بيشترين فراوانى مربوط به خصوصيات

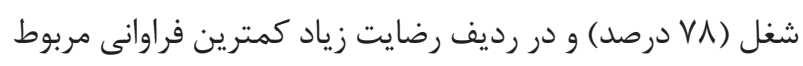

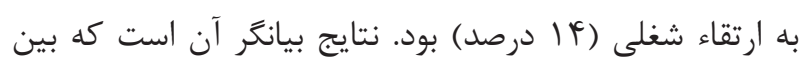

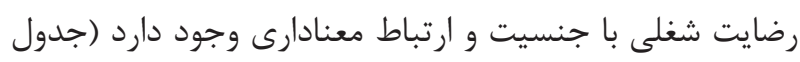

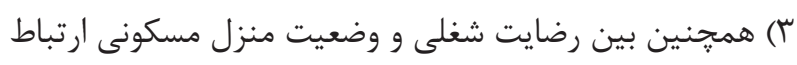

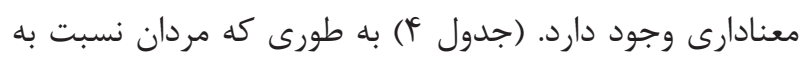
جدول r - ارتباط بين جنسيت و رضايت شغلى واحدهاى يثوهش جدول

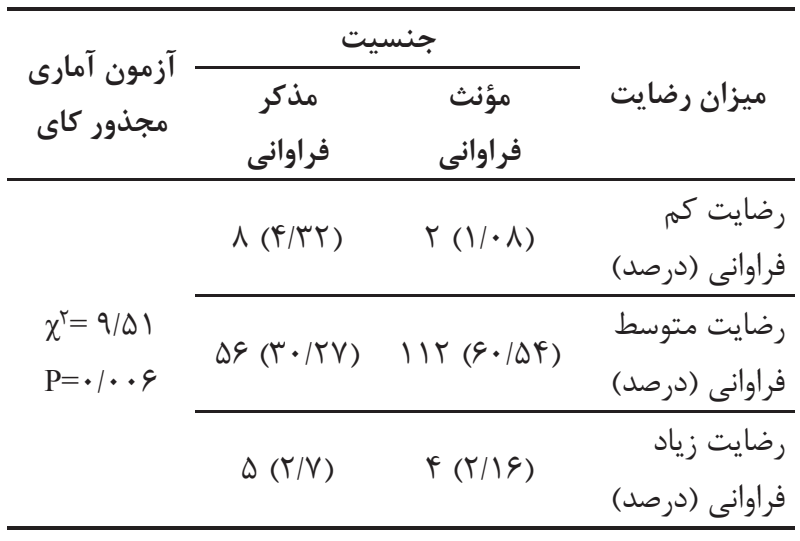

جدول F - ارتباط بين وضعيت مسكونى و رضايت شغلى واحدهاى يزوهش

\begin{tabular}{|c|c|c|c|c|}
\hline \multirow{2}{*}{ 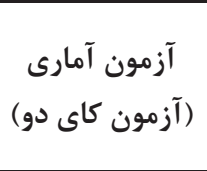 } & \multicolumn{3}{|c|}{ ميزان رضايت } & \multirow[b]{2}{*}{ وضعيت مسكونى } \\
\hline & فراوانى (درصدايت زياد & فراوانى (درصد) & فراوانى (درصد) & \\
\hline \multirow{5}{*}{$\begin{array}{c}\chi^{r}=9 / \Delta \\
P=\cdot / \cdot r r\end{array}$} & r (1/9 & $\Delta V(r \cdot / \Lambda r)$ & $\cdot(\cdot)$ & ملكى \\
\hline & $1(\cdot / \Delta r)$ & G. $(T Y / F T)$ & $\Delta(Y / V)$ & استيجارى \\
\hline & $\cdot(\cdot)$ & $r \cdot(|g / r|)$ & $r(1 / q \mu)$ & سازمانى \\
\hline & $r(1 / 9 \mu)$ & $r \mid(\mid l / r \Delta)$ & $r(1 / \cdot 1)$ & يدرى \\
\hline & $\vee(\Gamma / \vee \wedge)$ & $191(9 \cdot|\wedge|)$ & $1 \cdot\left(\Delta / F^{|c|}\right)$ & كل \\
\hline
\end{tabular}


منجر به بهبودى شرايط ايمنى بيمار گردد (V) (V). مطالعه كوشا و

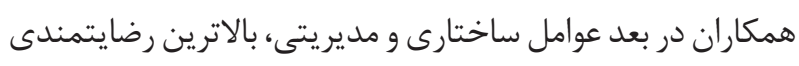

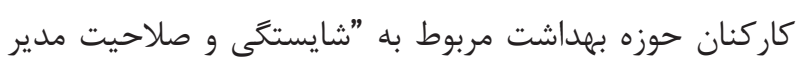

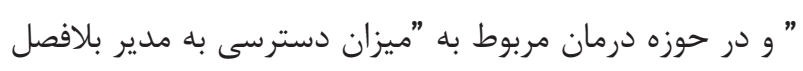

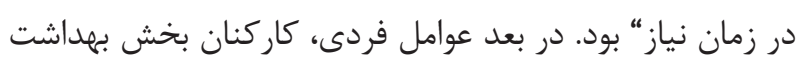

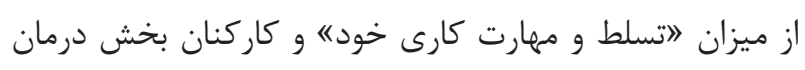

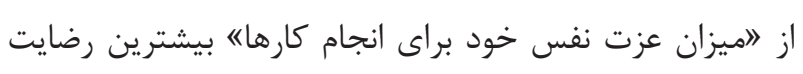

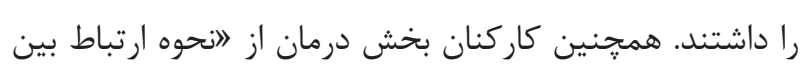

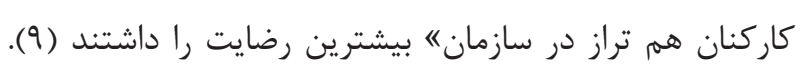

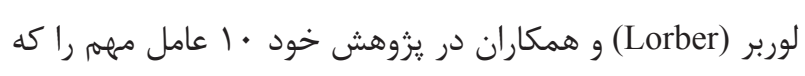
مديران و كار كنان بر رضايت شغلى مؤثر مى دانستند شامل: روابط خوب در محل كار، يرداخت به موقع، فرصت براى ارتقاء، امكانات

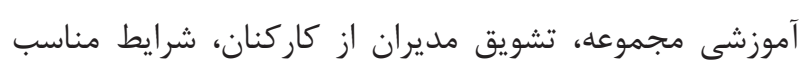

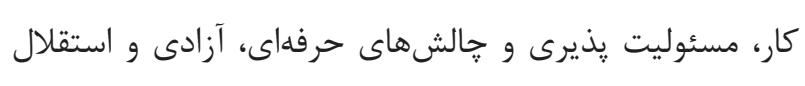

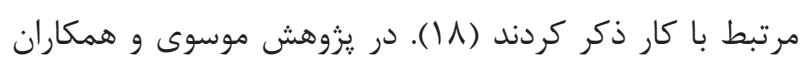
كاركنان مورد مطالعه دو عامل حقوق و دستمزد مناسب و فراهم مردم بودن مزاياى جانبى را جزء با اهميتترين عوامل بهداشتى مؤثر

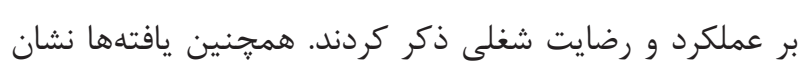
داد كه دو عامل احساس مسئوليت در كار و مورد علاقه بودن كار

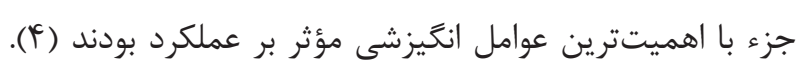

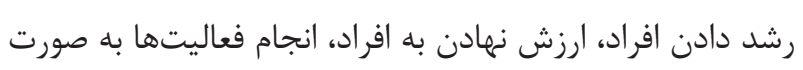

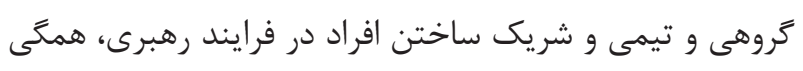

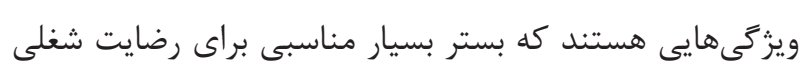
كاركنان فراهم مى كند. سرمايه انسانى و اهميت آن در سازمان بر كسى بوشيده نيست.

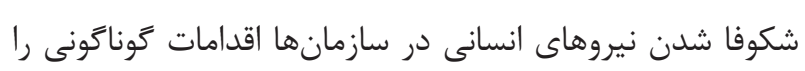
مىطلبد كه يكى از آنها اقدامات تأمين رضايت شغلى كاركنان أنسان دان

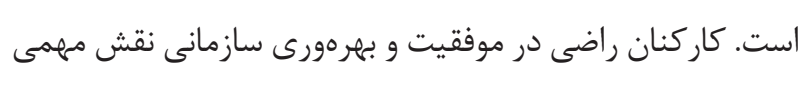

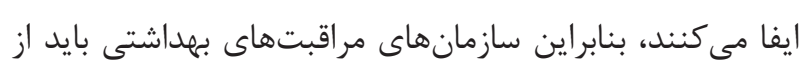

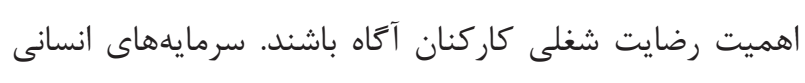

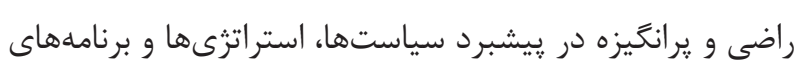

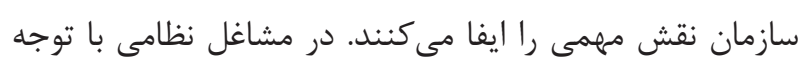
به مأموريتهاى ييجيده حرفهاى، قوانين سخت كارى و شرايط محيط كار لازم است به رضايت شغلى يرسنل توجه ويزهاى انجام

\section{بحث و نتيجه كيرى}

در فضاى رقابتى و يوياى امروز در سازمانها، رضايت شغلى يكى دئى از موضوعات مهمى است كه قادر به توصيف شغل يا شرايط حاكم بر شغل است، جرا كه از طريق رضايت شغلى، شادابى و مسرت به به ماديه

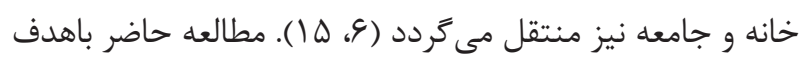

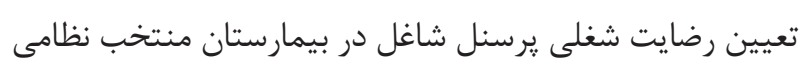

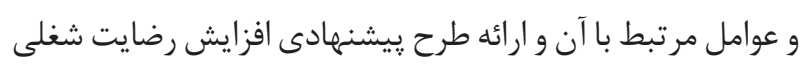

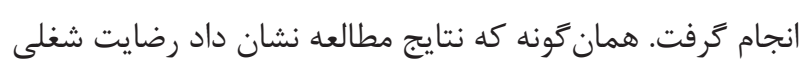
واحدهاى يزوهش در حد متوسط بود. نتايج مطالعه ما با مطالعه

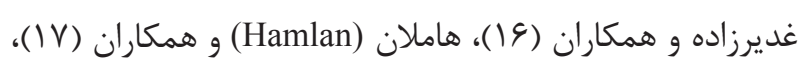

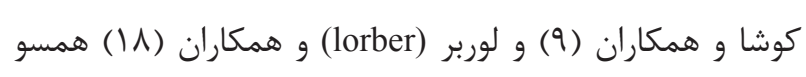

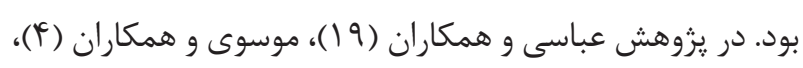
نحرير و همكاران (V)، رضايى و همكاران (Y) (Y)، سالار و همكاران

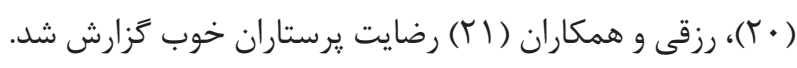

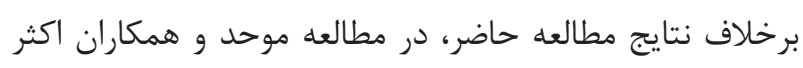
يرستاران ناراضى بودند. در مطالعه حاضر از بين ينج حيطه ارزيابى رضايت شغلى، بيشترين بودند

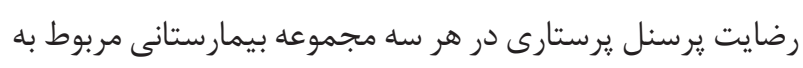

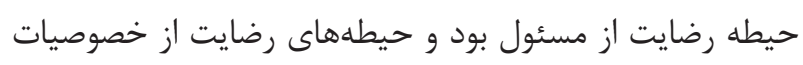

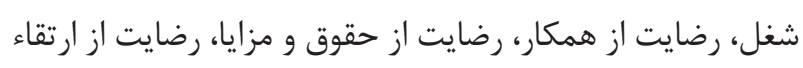

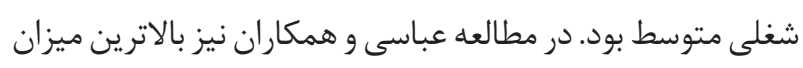
رضايت مربوط به سريرست و كمترين ميزان مربوط به حقوق و

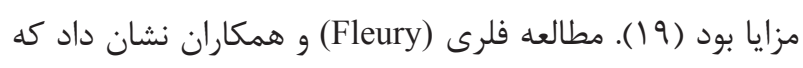

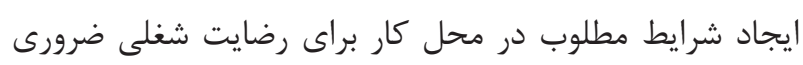

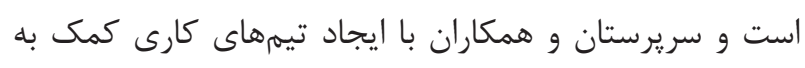
كاهش حجم كار، جلوگيرى از فرسودىى و اثرات عاطفى مى كنند.

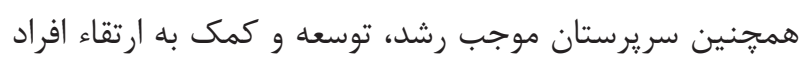

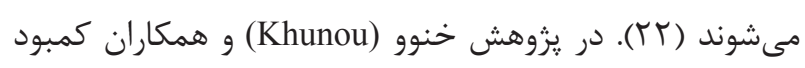

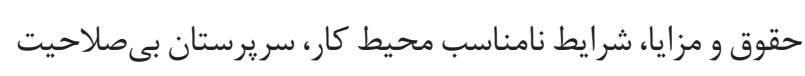

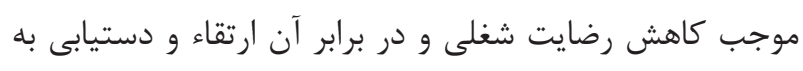

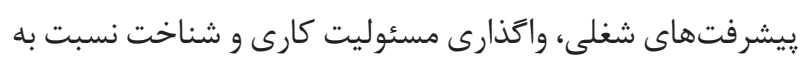
حرفه موجب افزايش رضايت شغلى يرستاران بود (^). در مطالعه هاملان و همكاران روابط بين حرفهاى، محيط همكارى خوب يزشك و يرستار موجب افزايش رضايت شغلى بيمار شده و مىتواند 


$$
\text { مربوط به زمينه فعاليت افراد انجام گيرد. }
$$

$$
\text { تشكر و قدردانى }
$$

اين يزوهش با حمايت مالى مشترك دانشكده يرستارى و مركز طب دريا دانشعاه علوم يزشكى بقيه ا... (عج) انجام شده است.

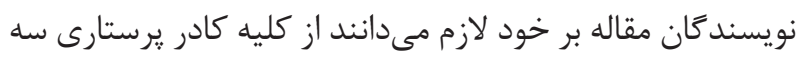
بيمارستان منتخب نظامى و آقاى حسين باقرى يرسنل بازنشسته مئه مركز طب دريا كه در توزيع و جمعآورى يرسشنامهها كمال همكارى را داشتند، تقدير مىنمايند.

تضاد منافع هيج گَونه تضاد منافعى بين نويسند

\section{References}

1- Mostafaee F, Roshan R. The Relationship between Personality Characteristics and Job Satisfaction among the Police Officers of Tehran Railway. J Police Knowledge. 2010;11(4):183-206.

2- Bagheri S, Kousha A, Janati A. Factors affecting nurses' job satisfaction: a systematic survey. Hakim Health Sys Res. 2012;15(2):130-9.

3- Gholami Phesharaki M, Talebian D, Aghamiri Z, Mohammadian M. Reliability and Validity Assessment of Najmejia Job Satisfaction Questionnaire. JAMS. 2011;14(5):63-9.

4- Mousavi S, Movahedirad S. The study of job satisfaction among nurses in Tehran military hospitals in 2014. NPWJM. 2015;2(5):183-9.

5- MousaviTabar Y, Rahmani R, Sirati Nir M, Abaszadeh Z. Influence factors in job satisfaction of nurses in the selected military and civil hospital in Tehran. NPWJM. 2013;2(17):34-9.

6- Ijadi Maghsoodi A, Azizi-ari I, Barzegar-Kasani Z, Azad M, Zavadskas E, Antucheviciene J. Evaluation of the Influencing Factors on Job Satisfaction Based on Combination of PLS-SEM and F-MULTIMOORA Approach. Symmetry. 2018;11(1). DOI: 10.3390/sym11010024

7- Nehrir B, Ebadi A, Sh T, AA K, Honarvar H. Relationship of job satisfaction and organizational commitment in hospital nurses. J Mil Med. 2010;12(1):23-6.

8- Khunou SH, Davhana-Maselesele M. Level of job satisfaction amongst nurses in the North-West Province, South Africa: Post occupational specific dispensation. Curationis. 2016;39(1):1438. DOI: 10.4102/curationis.v39i1.1438 PMID: 26974827

9- Kousha ASB, Janati A, Farahbakhsh M. Comparative study of job satisfaction among health. J Mil Med. 2012;14(2):105-12.

10- Clarke SP. Job satisfaction survey report. Nursing. 2007;37(12
شود تا كيفيت ارائه خدمات و مراقبتهاى بيماران ارتقاء يابد. از طرفى تداخل خدمات و مراقبتهاى يرستارى با درگيرىهاى شغلى و محدوديتهاى نظامى مىتواند از دلايل افت رضايت شغلى يرستاران شاغل در بيمارستانهاى نظامى باشد. محدوديتهاى اين يزوهش شامل عدم امكان دسترسى به حجم جامعه يزوهش به دليل موقعيت نظامى سه مركز، طولانى شدن فرايند نمونه واحدهاى يزوهش و احتمال خوددارى از ارائه نظرات صحيح افراد در تكميل يرسشنامهها از محدوديتهاى اصلى بود. بر همين اساس محققين ييشنهاد مىنمايند در آينده مطالعات با نمونههاى بيشتر و در محيطهاى يزوهشى متنوعتر و همجنين مطالعات كيفى براى

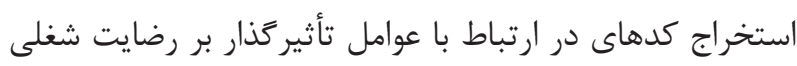

Pt.1):43-7. DOI: 10.1097/01.NURSE.0000302553.09732.2e PMID: 18090633

11- Movahhed M, Moghaddam Y. Survey of Job Satisfaction and the Factors Affecting it, with Employed Nurses in the Educational and Curative Centers of Uromieh University of Medical Sciences, 1380. J Urmia Nurs Midwifery Fac. 2004;2(2):16-20.

12- Asegid A, Belachew T, Yimam E. Factors Influencing Job Satisfaction and Anticipated Turnover among Nurses in Sidama Zone Public Health Facilities, South Ethiopia. Nurs Res Pract. 2014;2014:909768. DOI: 10.1155/2014/909768 PMID: 24707397

13- Smith P, Kendall M, Hulin C. The measurement of satisfaction in work and retirement: A strategy for the study of attitudes. 1969. Chicago, Ill. Rand McNally oxford england; 1969.

14- Rezaei H, Bahmanbijari B, Beigzadeh A, Askari S, Khadir E. Job satisfaction and organizational commitment of nurses in teaching hospitals affiliated to Kerman University of Medical Sciences. IJME. 2017;17:245-50.

15- Bahadori M, Babaei M, Mehrabian F. Prioritization of factors influencing job motivation in employees of a military center using analytical hierarchy process (AHP). J Mil Med. 2013;14(4):23744.

16- Adib-Hajbaghery M, Gadirzadeh Z, Abadi M, Arabi M. Job stress, job satisfaction, and related factors in a sample of Iranian nurses. Nursing and Midwifery Studies. 2017;6(3). DOI: 10.4103/nms. nms_26_17

17- Hamlan N. The Relationship Between Inter-Professional Collaboration, Job Satisfaction, and Patient Safety Climate for Nurses in a Tertiary-Level Acute Care Hospital. The University of Western Ontario. 2015.

18- Lorber M, Skela Savic B. Job satisfaction of nurses and identifying 
factors of job satisfaction in Slovenian Hospitals. Croat Med J. 2012;53(3):263-70. DOI: 10.3325/cmj.2012.53.263 PMID: 22661140

19- Abbasi A, Bahreini M, Yazdankhah Fard MR, Mirzaei K. Compare Clinical Competence and Job Satisfaction Among Nurses Working in Both University and Non-University Hospital in Bushehr 2015. Iranian South Medl J. 2017;20(1):77-89. DOI: 10.18869/acadpub. ismj.20.1.77

20- Salar AR, Zare S. Job Burnout Rate among Zahedan University of Medical Sciences Staff. Biology and Medicine. 2016;8(5). DOI: $10.4172 / 0974-8369.1000309$
21- Rezghih Shirsavar H, Mousavi M. The Relationship between Job Satisfaction and Behavior of Employees Employed in the Medical Unit Islamic Azad University of Tehran. Healthcare Management J. 2014;3:19-27.

22- Fleury MJ, Grenier G, Bamvita JM. Job satisfaction among mental healthcare professionals: The respective contributions of professional characteristics, team attributes, team processes, and team emergent states. SAGE Open Med. 2017;5:2050312117745222. DOI: 10.1177/2050312117745222 PMID: 29276591 